in the carnage of the Western front. In 1930 it was made into a Hollywood film, All Quiet on the Western Front, which was shown all over the world - except in Germany. When the film's distributors tried to show it in Berlin, Hitler's friend Joseph Goebbels organized a riot in the cinema. Further Nazi demonstrations and violent protests against the film followed. The Weimar government then banned the film throughout Germany because the Nazis considered it unpatriotic.

This episode explains a mystery in my own family. One of my relatives, who is now 94 years old, has lived in Germany all her life and grew up in the Weimar years. Many years ago I gave her Remarque's book to read and she found it very moving. "This book is wonderful," she said. "Why didn't they let us read it when it was published? That was before the Hitler time, but we were told it was disgusting and shameful, and that respectable people should not read it." So the respectable Germans of her generation, even those who were not Nazis, did not read Remarque. I had always wondered why, and now I know.

Freeman J. Dyson is at the Institute for Advanced Study, Princeton, New Jersey 08540, USA.

\section{...…ㄱ...... Getting heated over glaciation}

\section{Snowball Earth \\ by Gabrielle Walker \\ Crown Publishers: 2003. 256 pp. \$24.95 \\ Bloomsbury: 2003. 16.99}

\section{Euan Nisbet}

Snowballs can be fun. But when they have rocks in them, the arguments start, just as between Calvin and Susie in the comic strip Calvin and Hobbes. Snowball Earth is a Hobbes-eye view of the succession of missiles, ambushes and strategies in the longrunning skirmishes over the idea that the Earth may have become so cold 600 million years ago that even the tropics froze over. The scene is superbly described, and each throw is meticulously followed from the gathering of the snow to the splat on the target. But a warning: it gets personal and gossipy - snowballologists will need many measures of generous spirit to read this.

The snowball debate first rumbled around the darker recesses of the Spitsbergen room of Cambridge University's Sedgwick Museum 30-40 years ago. Brian Harland had suggested that there had been a great glaciation just before the start of the Cambrian period. Few believed him beyond the confines of the Sedgwick Museum, and even within I recall scepticism (including my own). The new ideas of plate tectonics could surely explain most things, even glacial sediments closely juxtaposed to tropical deposits. We knew that rapid continental motion occurred: India's march northwards showed that. Nevertheless, Harland serenely held to his views, supported later by Mike Hambrey. Then Joe Kirschvink published the briefest of notes on 'Snowball Earth', lost in a fine book, The Proterozoic Biosphere, which was widely read but so vast that its most common use is as a doorstop. There languished the notion.

The Canadian government intervened, deciding in its wisdom to deconstruct what was then arguably the finest (and economically most useful) national geological survey on Earth. Paul Hoffman, a distinguished Arctic field geologist, was unable to work as usual. He departed south and turned his attention to Namibian rocks laid down in the latest Proterozoic, the time just before the Cambrian. What he found were rocks deposited in glacial conditions. But puzzlingly, these rocks were closely juxtaposed with carbonate sediments laid down in warm conditions. Moreover, the succession was very similar to the Spitsbergen rocks that Harland's group had studied.

The 'snowball' idea states that around 600 million years ago there were episodes when even in the tropics the ocean surface froze. The white, icy planet then reflected so much sunlight that the condition persisted. Life luckily survived, presumably in Noah's Arks of habitat in warm water around hot springs or photosynthesizing in open channels in the icy ocean. Eventually, as carbon dioxide continued to degas from volcanoes, the atmospheric greenhouse became so strong that tropical melting began. As ice melted, the newly darkening planet would have absorbed heat, a positive feedback leading to runaway warming. This would have been exacerbated by the release of dissolved carbon dioxide from the heating oceans and methane from vast hydrate stores, so the snowball suddenly flipped to a hothouse hell.

Gabrielle Walker recounts in racy detail the chain of discovery. Hidden in the social froth, she provides nuggets of gold: simple explanations of complex evidence. Carbon isotopes, facies analysis, methane hydrates, metazoan evolution - complicated topics all - slip down with spoonfuls of scandal sugar. The book lucidly exposes the observations that shaped the hypothesis and its testing, the critics and the bases of their criticisms, and the subsequent growth of the idea as the debate provoked more and more insights. Just as Sir Harold Jeffreys' opposition to continental drift was crucial in provoking a rigorous theory of plate tectonics, so Walker shows clearly how disputes about the snowball (for example, the contrary views of Nick Christie-Blick), brought deeper understanding.

Did Snowball Earth really happen? Sitting next to a scientific knight of excellent judgement at the end of Hoffman's peroration on receiving the Wegener Medal in 2001, I noted his warm applause (did he stamp his sandals? Was he clapping act or fact?), while I was still weighing the balance. Snowball Earth is entering the textbooks. Walker quotes a wildly improbable (but splendidly diverting) speculation that Hoffman will become a lord. In reality, like most scientists, geologists welcome but do not seek applause or rewards (or they'd have chosen easier and more remunerative jobs): their thrill is the chase. The details (snowball or slushball) remain hotly argued, and there are many false alarms and excursions, but there is an emerging consensus that something odd is being hunted down.

Is it important? The notion that Earth's climate has alternative stable states and can flip between them carries a warning for today. The stable climate of the past 10,000 years may be a freak — the hidden nightmare monsters that made the snowball may still be out there, especially methane. The Arctic sea floor and the continental shelves worldwide have widespread methane hydrates that will be released by warming. We are already turning Spitsbergen into fried ice-cream. Is it time to learn from geology's nightmares? Kyoto began the estrangement between the United States and Europe: maybe it could also begin the reconciliation. To get technical, either by a stand-alone methane agreement, or by resetting Kyoto's timescale for calculating global-warming potential from 100 years to a 'poor-nationfriendly' 20 years, and hence by placing more emphasis on vigorous cuts in methane emission, 
we may find a cheap-to-implement accord, acceptable to the United States, the European Union and poorer nations, that actually tackles radiative warming now, within a few decades.

Noah's rainbow was a covenant for all living species, not just humanity. Humanity's emissions now wilfully block the infrared part of that promise. If our nations corrupt the rainbow, is it time to search out supplies of gopher wood and start collecting eukaryotes two-by-two, trying to keep our genetic company afloat while the greedy world goes into liquidation? In the meantime, Snowball Earth makes good spring reading. And when you are done, pass it on to any handy teenager, who will be enthralled, if not by the science, then by the storytelling.

Euan Nisbet is in the Atmospheric Group,

Department of Geology, Royal Holloway,

University of London, Egham,

Surrey TW20 OEX, UK

\section{Gould and God}

\section{A Devil's Chaplain}

by Richard Dawkins,

edited by Latha Menon

Weidenfeld \& Nicolson: 2003. 320 pp.

$£ 16.99$

\section{Jerry A. Coyne}

The original 'Devil's chaplain' was Robert Taylor, an apostate priest and self-styled 'infidel missionary' whose rabble-rousing entourage stormed into Cambridge in 1829 - halfway through Charles Darwin's undergraduate career. Taylor's brew of atheism and republicanism held no allure for young Darwin, then a conventional Christian thoroughly steeped in the hierarchical values of nineteenth-century Britain. But Darwin never forgot Taylor's nickname. In 1856, pondering the brutal inefficiency of natural selection, Darwin wrote to his friend Joseph Hooker: "What a book a devil's chaplain might write on the clumsy, wasteful, blundering, low and horribly cruel works of nature!" Although creationists constantly remind us that On the Origin of Species is a satanic work, Darwin never aspired to succeed Taylor: he was too shy of controversy, too worried about the happiness of his devout wife.

Richard Dawkins, however, is more than happy to step into Taylor's shoes. Religion, writes Dawkins, is a "malignant infection" of the human mind. Six of the 32 essays in this eclectic collection (culled largely from the British press) address religion either directly or indirectly, a surprising statistic for a science writer whose chair at Oxford University is dedicated to the public understanding of science. However, another six essays attack further impassable routes to knowledge (such as homoeopathy, crystal worship and postmodernism). Clearly, Dawkins sees his brief as not only popularizing science, but demolishing its competitors.

Dawkins' other major bugbear - and the main non-divine theme of $A$ Devil's Chaplain - is the late Stephen Jay Gould. Dawkins offers here a gracious tribute to Gould, but also turns his incisive analytical mind and lucid prose against Gould's ideas with devastating effect. For example, Gould's notion that the evolutionary processes that shaped the early history of life (with new phyla being produced) differ qualita-

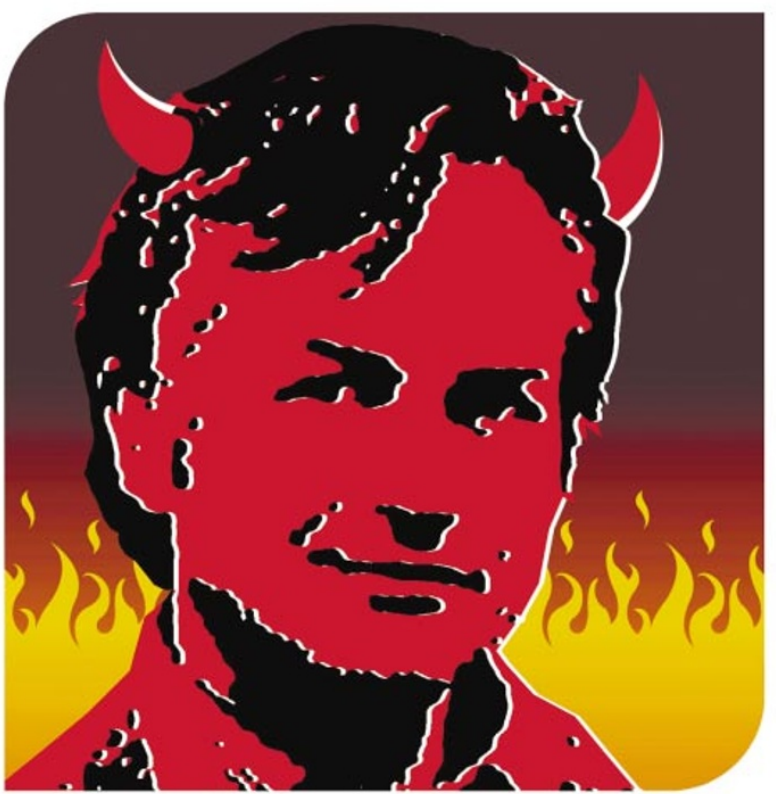
tively from the processes that direct more recent evolution (with only lower-level taxa appearing) is deflated in two deft sentences: "It is though a gardener looked at an old oak tree and remarked wonderingly: 'Isn't it strange that no major boughs have appeared on this tree recently. These days, all the new growth appears to be at the twiglevel!'."

In fact, the critiques of Gould and God are not as unrelated as they appear. As this collection makes clear, Dawkins is a fierce advocate of scientism, the philosophy that genuine truths - as opposed to spiritual or personal 'truths' that are not universally held - can be found only through the scientific method. Gould was not as strict: he was an accommodationist, insisting in works such as Rocks of Ages that both religion and science are independent and valid domains of enquiry. Dawkins, then, is both scientifically and philosophically opposed to Gould. Several books have been written about the scientific arguments between Gould and Dawkins, but Dawkins aficionados outside Britain have had little exposure to his withering assaults on religion, pseudoscience and accommodationism. It's a rare treat to see him sail into battle, prose and logic perfectly attuned to the destructive business at hand. I should add that A Devil's Chaplain is not wholly focused on religion and Gould: it also includes obituaries of friends, and essays on ethics, genetic determinism, Africa (Dawkins spent much of his childhood in Kenya) and meme theory (the collection's only low point, given my view that 'mimetics' is an extended tautology that has yielded no real understanding of human culture). But it's in religious territory that A Devil's Chaplain is most compelling.

"Modern theists," writes Dawkins, "might acknowledge that, when it comes to
Baal and the Golden Calf, Thor and Wotan, Poseidon and Apollo, Mithras and Ammon $\mathrm{Ra}$, they are actually atheists. We are all atheists about most of the gods that humanity has ever believed in. Some of us just go one god further." But Dawkins goes beyond a mere defence of atheism. He also subscribes to the American writer H. L. Mencken's dictum that: "We must respect the other fellow's religion, but only in the sense and to the extent that we respect his theory that his wife is beautiful and his children smart." Why, asks Dawkins, should the public give religious arguments any more credibility than arguments for other brands of nonscientific 'truth'? Curiously, Dawkins does not explore why religious ideas get undue respect. Surely one reason is that arguing about religion (especially when one participant is an atheist) is unproductive, likely to produce only mutual dislike. No rapprochement is possible between those whose beliefs derive from evidence and those whose beliefs either do not depend on evidence or are unshaken by contrary evidence. This is why science and religion are incompatible ways of viewing the world.

Dawkins' critique of religion rests on three points. First, because different faiths make very different claims about the world, they cannot all be true; and none of the claims (such as the bodily assumption of Mary into heaven) can be scientifically verified. Second, the choice among faiths is not based on rational consideration: the vast majority of people simply practice the religion of their parents. This is especially galling to Dawkins, who sees the easy indoctrination of children as a product of natural selection favouring the rapid spread of information between generations. Finally, Dawkins considers religions to be vehicles of evil because they facilitate the labelling 